\title{
Human Rights and Indigenous Peoples
}

\author{
Garth Nettheim
}

\begin{abstract}
The paper begins by noting the low level of reference to Indigenous Australians in the Commonwealth Constitution at the start of Federation, and goes on to discuss the limits to what was achieved by the 1967 amendments. The situation represents a marked contrast with the USA and Canada in terms of treaties and constitutional recognition. In Australia, particularly during the period of the 'Reconciliation' process in the 1990s, important steps were taken by Indigenous Australians to identify items of 'unfinished business' in a 'Statement of Indigenous Rights'.

However, there has been limited progress to meet these aspirations, and Australian law still lacks a tradition of recognition of human rights generally, let alone Indigenous rights.

International law, too, largely lacked recognition of human rights prior to the adoption in 1945 of the Charter of the United Nations. The brief references in the Charter were subsequently developed in a range of declarations and of treaties. These applied to people generally, with scant reference to Indigenous peoples. But, since the 1970s, there has been growing international recognition of the rights of Indigenous peoples under existing declarations and treaties. Since the 1990s, in particular, the UN system has established specific mechanisms for addressing such issues. On 13 September 2007, the General Assembly finally adopted a Declaration on the Rights of Indigenous Peoples.
\end{abstract}

\section{Indigenous Australians and the Commonwealth Constitution}

In 2007 Australia marked the $40^{\text {th }}$ anniversary of the 1967 Referendum, which was, indeed, an event worth celebrating. Of the 44 proposals that have been put to the electors to amend the Commonwealth Constitution, and of the eight of those 44 that actually got up, the 1967 referendum was the most successful. It involved some ten years of effective activism by Faith Bandler and other members of FCAATSI and their supporters before being accepted by $91 \%$ of the voters (Bandler 1989). However, important as it was, it did not frame rights. All it did was remove a limitation on Commonwealth legislative power. Constitution s. 51 as it came into operation in 1901 listed the topics on which the Commonwealth Parliament may legislate as including:

(xxvi) The people of any race, other than the aboriginal race in any state, for whom it is deemed necessary to make special laws. 
The referendum deleted the words 'other than the aboriginal race in any state'. It also deleted s.127 which had provided: 'In reckoning the numbers of the people of the Commonwealth, or of a State or other part of the Commonwealth, aboriginal natives shall not be counted'.

The Commonwealth Parliament could now pass laws for Aboriginal people in the States. It was widely expected that it would be more benevolent to them than State governments, such as that of Queensland in the days of Premier Bjelke-Petersen, and that it would override restrictive State laws. The validity of Queensland legislation was challenged in Koowarta v Bjelke-Petersen (1982) 153 CLR 168 on the basis (under Constitution s. 109) that the state legislation was inconsistent with a Commonwealth Act - the Racial Discrimination Act 1975 (Cth) (the RDA).

In response the Queensland government challenged the validity of the RDA itself. However, the High Court held that it was valid on the basis, not of the races power (s. 51 (xxvi)), but the external affairs power. This was because the RDA had been enacted to implement in Australian law the International Convention on the Elimination of All Forms of Racial Discrimination which Australia had ratified. One year later the High Court did uphold the validity of Commonwealth legislation on the basis of the races power in Commonwealth $v$ Tasmania (the Tasmanian Dam case) (1983) 158 CLR 1 - sections of the legislation authorised protection of Aboriginal sites. And a wide interpretation of the power was also given by the High Court in Western Australia v Commonwealth (Native Title case) (1995) 183 CLR 373.

These decisions involved Commonwealth legislation which was in fact beneficial to Aboriginal people. The question remained whether the races power might be used to their disadvantage. A partial answer was given by the High Court in Kartinyeri v Commonwealth (1998) 195 CLR 337. The Commonwealth Parliament had enacted the Hindmarsh Island Bridge Act 1997 (Cth) which removed the area of the proposed bridge from the protection available under an earlier Commonwealth Act, the Aboriginal and Torres Strait Islander Heritage Protection Act 1984 (Cth). Five out of six of the High Court justices (Kirby J dissenting) held that the races power was not limited to legislating for the benefit of Indigenous Australians, at least where the Commonwealth was exercising the power in order to repeal or amend its own prior legislation. 
So in 2005 there was no impediment to the Commonwealth Parliament repealing the Aboriginal and Torres Strait Islander Commission Act 1989, thus abolishing ATSIC, the national voice for Indigenous Australians. There was also no suggestion that various criticised features of the Northern Territory Emergency Response Act 2007 and associated legislation were beyond the power of the Commonwealth by reason of section 51 (xxvi). So, while the 1967 amendment removed a restriction on Commonwealth legislative power, it fell short of conferring a right.

\section{North American contrasts}

One may ask why, in the first place, the framers of the Constitution had inserted the initial restriction on the legislative power of the federal parliament. To find a reason, one may consider by way of contrast the Constitutions of the USA and Canada. In these two otherwise comparable nations, we find federal Constitutions which, from the start, gave primary legislative power for Indigenous peoples to the federal level of government. The 1901 Australian Constitution left primary law-making power with the States.

One reason has to be that in North America the British had negotiated treaties since the beginning of contact with Indigenous peoples. They did not do so in all parts of what became the USA and Canada. Nor did they always abide by the treaty commitments which they did take on. But such treaties did serve to recognise the sovereignty and territorial rights of the particular people they were dealing with as a basis for British settlement, and as a basis for the relationship thereafter. By contrast, no such treaties were negotiated at the onset of British settlement in the Australian colonies, in spite of instructions issued to Cook in 1768 that he should seek 'the consent of the natives'. The reasons for this departure from prior colonial practice - and, indeed, later practice in New Zealand - are various (McRae et al. 2009).

This treaty legacy in North America must have been influential in the formulation of constitutional provisions when federal constitutions were adopted for the USA and for Canada. The US Constitution treats Indian nations as separate entities in the legislative power assigned to Congress in art.1, s. 8:

3. To regulate Commerce with foreign nations, and among the several States, and with the Indian tribes'. 
In a series of cases in the US Supreme Court, notably Worcester v State of Georgia 31 US 350; 6 Pet 515 (1832), Chief Justice Marshall characterised the Indian peoples as ‘nations’ but of a particular type, namely 'domestic dependent nations', which retain their inherent sovereignty but are under the protection of the federal government of the US. The Court's acknowledgement, in this case, and other cases of the period, of Indian title and a degree of Indian sovereignty have been fundamental in later US jurisprudence. (Nonetheless there has been some erosion by Congress of Indian sovereignty and Indian title, and of the powers of tribal governments and tribal courts.)

The British North America Act 1867 (UK) for Canada’s federation likewise gave primary lawmaking power with respect to Indians to the federal government, as does the current Constitution Act 1982. And s. 35 of the Constitution now specifically recognizes and affirms existing aboriginal and treaty rights.

In Australia, as noted, Indigenous peoples were left from the start at the mercy of the several colonial governments as they were established. This situation was preserved at Federation, with legislative power merely being shared from 1967. There was no spelling out of rights of Aboriginal and Torres Strait Islander peoples in the Commonwealth Constitution or State constitutions. Further, the various calls for a treaty - or treaties - since 1901 have not yet produced a result (Brennan et al. 2005). Michael Detmold in 1985 wrote:

\footnotetext{
'No entry has been made by Aborigines into the new legal order. . The Australian Commonwealth will not be a just commonwealth until the nature of the Aboriginal entry and its legal consequences are recognised'.
}

On this analysis the 'constituting' of the Australian nation remains incomplete. This discussion about treaties focuses on the highest level of relations between Indigenous Australians as a collectivity (or collectivities) and Australia. However, at other levels there has increasingly been a range of agreements made between particular Indigenous peoples and governments, and sometimes with other parties such as mining companies (Langton et al. 2004). 


\section{The Agenda}

At the national level, one can reasonably ask what are the issues of 'unfinished business' that Indigenous Australians might wish to have addressed and resolved, possibly by means of a treaty or some other forms of agreement? These have been discussed over the years in a variety of contexts including the context of the 'Reconciliation' process through the 1990s and in late 1999 were formulated into an agenda. In September of that year, ATSIC convened a meeting of some 60 Indigenous leaders to discuss future developments. A list of items of "unfinished business" was developed as a Statement of Indigenous Rights, and the leaders sought to have this embodied in an agreement with governments. The list of matters is as follows:

- Equality

- Distinct characteristics and identity

- Self-determination

- Law

- Culture

- Spiritual and religious traditions

- Language

- Participation and partnerships

- Economic and social development

- “Special measures”

- Education and training

- Land and resources

- Resource development

- Self-government

- Constitutional recognition

- Treaties and agreement

- Legislation (MacRae 2009, p. 694).

Such an agenda can be said to represent aspirations - matters which Indigenous Australians wish to be addressed. 
Yet the question remains, Do these matters represent rights? And more broadly, does Australian law recognise rights at a fundamental level? Generally speaking, it does not. Under our constitutions people do have rights such as the right to vote for members of Parliament. It is the case that people do have important rights under law. However, to a considerable extent our Commonwealth and State parliaments are free to override such rights. In other words, Australia does not have a constitutional Bill of Rights on the US model either at federal or state level. In the last few years we have indeed seen the enactment of 'bill of rights' measures in the ACT and Victoria, as ordinary non-constitutional legislation, but such rights can be overridden by the respective parliaments.

Canada adopted a legislative Bill of Rights in 1960 and followed up in 1982 with the enactment of a revised Constitution which includes a Charter of Rights and Freedoms. Apart from that Charter, s. 35 of the Canadian Constitution provides:

(1) The existing Aboriginal and treaty rights of the Aboriginal peoples of Canada are hereby recognized and affirmed.

(2) In this Act, 'Aboriginal peoples of Canada’ includes the Indian, Inuit and Metis peoples of Canada.

(3) For greater certainty, in sub-section (1) 'treaty rights' includes rights that now exist by way of land claims agreements or may be so acquired.

(4) Notwithstanding any other provisions of this Act, the aboriginal and treaty rights referred to in sub-section (1) are guaranteed equally to male and female persons.

\section{Indigenous rights and human rights}

One of the signal features of the Charter of the United Nations, adopted in 1945, is that it specifically recognises human rights. It does not define them beyond references, as in Article 1 , to the 'principle of equal rights and self-determination of peoples' and the need for 'respect for human rights and for fundamental freedoms for all without distinction as to race, sex, language, or religion'. Human rights were subsequently set out in the Universal Declaration of Human Rights, adopted in 1948, and they were spelled out in treaty form in 1966 in two instruments: the 
International Covenant on Economic, Social and Cultural Rights (ICESCR), and the International Covenant on Civil and Political Rights (ICCPR).

Australia has ratified both Covenants and is therefore bound by their terms in international law. It has also ratified other human rights treaties such as the International Convention on the Elimination of All Forms of Racial Discrimination, the International Convention on the Elimination of All Forms of Discrimination against Women, the Convention on the Rights of the Child, and the Convention against Torture and Other Cruel, Inhuman and Degrading Treatment or Punishment.

In terms of domestic law, we have legislated against discrimination on the basis of race and gender (and on other bases) at State and Federal levels. The national Human Rights and Equal Opportunity Commission (HREOC) - now known as the Australian Human Rights Commission (AHRC) - includes Commissioners with responsibility for human rights generally, race discrimination, sex discrimination, age discrimination, disability discrimination - and the Aboriginal and Torres Strait Islander Social Justice Commissioner. This raises the question of how these human rights standards at international level relate to Indigenous peoples?

\section{International Human Rights Law and Indigenous peoples ${ }^{1}$}

For the most part the key multilateral treaties and other international instruments have not referred to Indigenous peoples at all. The first acknowledged breakthrough came from the International Labour Organisation which had, as long ago as 1921, begun to adopt a series of conventions dealing with Indigenous workers. In 1957 it adopted a more comprehensive ILO Convention Concerning the Protection and Integration of Indigenous and Other Tribal and SemiTribal Populations in Independent Countries (No 107). In 1989 the Organisation adopted a revised instrument, the ILO Convention Concerning Indigenous and Tribal Peoples in Independent Countries (No 169).

\footnotetext{
${ }^{1}$ This section draws from Garth Nettheim, 2007, 'Human Rights and Indigenous Reconciliation in Australia', 10 The Flinders Journal of Law Reform, vol.10, pp. 170-171.
} 
By contrast, the United Nations, starting in 1982, took much longer to develop an instrument relating comprehensively to the rights of Indigenous peoples. Indeed this process can be traced further back, to a 1971 decision of the Sub-Commission on the Prevention of Discrimination and the Protection of Minorities to commission a study of the problems of the world's indigenous populations. This study, known as the Martinez Cobo study, was eventually published in 1984: Study of the Problem of Discrimination against Indigenous Populations. The UN process of developing an instrument was initially vested in the five-member expert Working Group on Indigenous Populations (WGIP), working over the years with growing input from Indigenous peoples from around the world. However, the UN's 'core' human rights instruments have been invoked with some success by Indigenous peoples over the years.

Note, in particular, Article 27 of the ICCPR:

In those States in which ethnic, religious or linguistic minorities exist, persons belonging to such minorities shall not be denied the right, in community with other members of their group, to enjoy their own culture, to profess and practise their own religion, or to use their own language.

One of the 'core' human rights treaties extends this wording specifically to Indigenous peoples in Article 30 of the 1989 Convention on the Rights of the Child.

Among the other core instruments, I single out the 1965 International Convention on the Elimination of All Forms of Racial Discrimination. Article 5 spells out the categories of rights which are to be enjoyed without discrimination on the basis of race (etc), including:

(d)(v) The right to own property alone as well as in association with others;

(vi) The right to inherit; ...

Australia, in 1975, ratified the Convention, and the Commonwealth Parliament enacted the Racial Discrimination Act, 1975 (Cth) to implement the convention's requirements in Australian law. The above provision played a critical role in the continuation and the ultimate success of the Mabo litigation (Nettheim 1999). In the period since the enactment of 1998 amendments to the Native Title Act 1993 (Cth) the Committee on the Elimination of Racial Discrimination has 
criticised Australia for breach of its obligations under the Convention. Generally speaking, the 'core' human rights treaties have been interpreted by their treaty committees and others as applicable to Indigenous peoples’ interests and concerns (Anaya 2004).

\section{Declaration on the Rights of Indigenous Peoples}

The UN's Draft Declaration on the Rights of Indigenous Peoples was eventually approved in June 2006 by the Human Rights Council. Subsequently, on 13 September 2007, it was approved by majority vote of the UN's General Assembly. Four states voted against adoption and these were Australia, Canada, New Zealand and the USA. However, on 3 April 2009 the Australian government announced that it now supports the Declaration.

One of the fascinating dimensions to the process of developing the Declaration was the extent to which representatives of the world's Indigenous peoples (said to number over 300 million) were able to agree on the issues that affect them and on the appropriate language in which to assert their rights and interests.

Megan Davis (2007) provides a valuable account of the process leading to the adoption of the Declaration, and of its content and significance.

\section{Content of the Declaration}

The Declaration is broadly divided into themes: self-determination and its exercise; threats to the survival of Indigenous peoples; cultural, religious, spiritual and linguistic identity; education and public information; participatory rights; and lands and resources.

Articles 1-6 recognise general principles and rights to nationality, self-determination, equality and freedom from adverse discrimination. Article 3 recognises the Indigenous right to self-determination, consistent with common article 1 of the ICCPR and the ICESCR. 'Indigenous peoples have the right to self-determination. By virtue of this right they freely determine their political status and freely pursue their economic, social and cultural development’. 
Articles 7-10 deal with rights to life, integrity and security. Some states had difficulties in passing these articles in the context of emergencies and argued that they do not have to gain Indigenous consent prior to removal or relocation in circumstances of emergency.

Articles 11-13 codify rights pertaining to culture, spirituality and linguistic identity, including the right to practice and revitalise cultural traditions and customs as well as the right to maintain, protect and develop past, present and future manifestations of Indigenous culture. This includes archaelogical and historical sites, artefacts, performing arts or literature. These sections also highlight the right to maintain and protect and have access in privacy to religious and cultural sites and the right to repatriation of human remains.

Articles 14-17 deal with specific rights pertaining to education, information and labour rights, including the right of all children to all levels and forms of education, including the right of Indigenous people to establish and control their own educational systems and institutions. This body of rights also includes the right of Indigenous children living outside their community to be provided with access to education in their own culture and language.

Articles 18-23 are participatory rights elaborating development and other economic and social rights. This extends to Indigenous people participating fully at all levels of decision-making in relation to matters that affect their own lives. This section empowers Indigenous people with the right to special measures for immediate, effective and continuing improvement of their economic and social conditions, including in the areas of employment, vocational training and retraining, housing, sanitation, health and social security. Importantly, the Declaration also provides that states shall take measures, in conjunction with Indigenous peoples, to ensure that Indigenous women and children enjoy the full protection and guarantees against all forms of violence and discrimination.

Articles 24-30 deal with lands, territories and resources. This is the most controversial section of the Declaration. Article 26 states that Indigenous peoples have the right to 
own, develop, control and use lands and territories. This encompasses rights to the total environment of such lands, therefore comprising air, waters, coastal seas, sea-ice, flora and fauna and other resources which Indigenous people have traditionally owned or otherwise occupied or used. This includes the right to the full recognition of their laws, traditions and customs, land-tenure systems and institutions for the development and management of resources, and the right to effective measures by states to prevent any interference with, alienation of or encroachment upon these rights.

Articles 31-36 explain how the right to self-determination can be exercised, including matters relating to internal local affairs such as culture, education, information, media, housing, employment, social welfare, economic activities, land and resources, and the environment. This section also deals with matters of citizenship and the capacity to determine one's own citizenship in accordance with customs and tradition. It enables Indigenous people to promote and maintain traditional judicial customs, procedures and practices.

Article 37 contains the right to conclude treaties, agreements or other constructive arrangements with states. Article 38 provides that the state, in cooperation with Indigenous peoples, shall take appropriate measures including legislative measures to achieve the ends of the Declaration and article 39 states that Indigenous people have the right of access to financial and technical assistance from states for the enjoyment of rights in the Declaration. Articles 40-46 are implementation rights expounding the role of the state and international organisations in recognising the rights provided in the Declaration (Davis 2007, pp. 60-61).

Davis makes the point that the Declaration does not constitute formal international law, let alone national law. 'However, as it is increasingly utilised and practised it may be that the Declaration will contribute to a growing body of customary international law’ Davis 2007, p. 59). Further, she notes that it has already influenced at least one national court in Belize in recognising Mayan customary land tenure (Davis 2007, p. 61, Nettheim 2008, p. 25). 
Victoria Tauli-Corpuz, Chair of the UN Permanent Forum on Indigenous Issues, made a statement on the occasion of the adoption of the Declaration and included a comment on its potential influence on International law (Tauli-Corpuz 2007, p. 2).

For the UN Permanent Forum on Indigenous Issues, the Declaration will become the major foundation and framework in implementing its mandate to advise members of the Economic and Social Council and the UN agencies, programmes and funds on Indigenous Peoples’ human rights and development. It is a key instrument and tool for raising awareness on and monitoring progress of Indigenous Peoples’ situations and the protection, respect and fulfillment of Indigenous Peoples' rights. It will further enflesh and facilitate the operationalization of the human rights-based approach to development as it applies to Indigenous Peoples. It will be the guide for States, the UN System, Indigenous Peoples and civil society in making the theme of the Second Decade of the World’s Indigenous Peoples, 'Partnership for Action and Dignity’, a reality.

The United Nations Permanent Forum on Indigenous Issues is explicitly asked in Article 42 of the Declaration to promote respect for and full application of the provisions of the Declaration and follow-up the effectiveness of the Declaration. On behalf of the Permanent Forum on Indigenous Issues, I commit the Forum's devotion to this duty.

This is a Declaration which sets the minimum international standards for the protection and promotion of the rights of Indigenous Peoples. Therefore, existing and future laws, policies, and programs on Indigenous Peoples will have to be redesigned and shaped to be consistent with this standard.

\section{Conclusion}

We have come a long way. At the level of nation states there has been some recognition of the rights of Indigenous peoples through the medium of treaties and, in some cases, constitutional recognition of rights. Australia has been an exception to this. There has also been, in countries comparable to Australia, some recognition of the human rights of peoples generally. Australia has been an exception to this, too, subject to the very recent statutory recognition provided in the 
ACT in 2004 and in Victoria in 2006. At the international level, recognition of human rights generally has been a feature of the United Nations system since its inception in the 1940s. Such recognition has been capable of extending to the particular concerns of Indigenous peoples, and over the years, there has been a steady accretion of decisions of treaty committees, courts and other bodies to the effect that it does so extend, in some areas at least.

Since the 1970s work has proceeded in the UN system to develop Indigenous-specific standards.

The new Declaration represents a landmark in that development, reinforced by the establishment of particular institutions such as the Permanent Forum on Indigenous Issues, the Special Rapporteur on Human Rights and Fundamental Freedoms of Indigenous Peoples, and the Expert Mechanism on the Rights of Indigenous Peoples. These international developments can, and should, influence the trend within Australian law towards stronger recognition of the rights of Aboriginal peoples and Torres Strait Islanders. Although it remains to be seen, through them we may even achieve Reconciliation.

\section{Bibliography}

Anaya, S. J. 2004, Indigenous Peoples in International Law ( $2^{\text {nd }}$ ed), Oxford University Press, New York.

Bandler, F. 1989, Turning the Tide, Canberra, Aboriginal Studies Press, Canberra.

Brennan, S., Behrendt, L., Strelein, L. \& Williams,G. 2005, Treaty The Federation Press, Sydney.

Davis, M. 2007, 'The United Nations Declaration on the Rights of Indigenous Peoples' Australian Indigenous Law Review, vol.11, no. 3, p. 55

Detmold, M. 1985, The Australian Commonwealth: A Fundamental Analysis of its Constitution, LBC Information Services, Sydney, pp. 62-66.

Langton,M., Tehan, M., Palmer, L. \& Shain, K. (eds) 2004, Honour Among Nations? Treaties and Agreements with Indigenous People, Melbourne University Press, Melbourne.

Nettheim,G. 1999, ' 'Retreat from Injustice’: The High Court of Australia and NativeTitle' in Gibney, M. \& Frankowski, S. (eds) Judicial Protection of Human Rights. Myth or Reality? Praeger, Westport, CT., pp. 163-174.

Nettheim,G. 2007, 'Human Rights and Indigenous Reconciliation in Australia', 10 The Flinders Journal of Law Reform, vol.10, pp. 170-171.

Nettheim, G. 2008, 'The Maya land Rights Case’ Indigenous Law Bulletin vol. 7, no. 2, p.25

Nettheim, G. in McRae, H. et al. 2009, Indigenous Legal Issues: Commentary and Materials (4th ed), Thomson Reuters, Pyrmont, chapters 3 and 13.

Tauli-Corpuz, V. 2007, 'Statement on the Occasion of the Adoption of the United Nations Declaration on the Rights of Indigenous Peoples', (2007) 11(3) Australian Indigenous Law Review vol. 11, no.3, p. 2. 